Research Paper

\title{
Copper resistance of different ectomycorrhizal fungi such as Pisolithus microcarpus, Pisolithus sp., Scleroderma sp. and Suillus sp.
}

\author{
R.F. Silva ${ }^{1}$, M. Lupatini ${ }^{2}$, L. Trindade ${ }^{2}$, Z.I. Antoniolli ${ }^{2}$, R.B. Steffen ${ }^{2}$, R Andreazza $^{3}$ \\ ${ }^{1}$ Department of Agronomy, Federal University of Santa Maria, Campus CESNORS, Frederico \\ Westphalen, RS, Brazil. \\ ${ }^{2}$ Department of Soil Science, Federal University of Santa Maria, Santa Maria, RS, Brazil. \\ ${ }^{3}$ Center of Engineering, Federal University of Pelotas, Pelotas, RS, Brazil.
}

Submitted: October 31, 2011; Approved: July 23, 2012.

\begin{abstract}
Environments contaminated with heavy metals negatively impact the living organisms. Ectomycorrhizal fungi have shown important role in these impacted sites. Thus, this study aimed to evaluate the copper-resistance of ectomycorrhizal fungi isolates Pisolithus microcarpus - UFSC-Pt116; Pisolithus sp. - UFSC-PT24, Suillus sp. - UFSM RA 2.8 and Scleroderma sp. - UFSC-Sc124 to different copper doses in solid and liquid media. The copper doses tested were: $0.00,0.25,0.5,0.75,1.0$ and $1.25 \mathrm{mmol} \mathrm{L}^{-1}$ in the solid medium and $0.00,0.32,0.64$ and $0.96 \mathrm{mmol} \mathrm{L}^{-1}$ in the liquid medium. Copper was amended as copper sulphate in order to supplement the culture medium MNM at pH 4.8, with seven replicates to each fungus-dose combination. The fungal isolates were incubated for 30 days at $28^{\circ} \mathrm{C}$. UFSC-Pt 116 showed high copper-resistance such as accessed by $\mathrm{CL}_{50}$ determinations (concentration to reduce $50 \%$ of the growth) as while as UFSC-PT24 displayed copperresistance mechanism at $0.50 \mathrm{mmol} \mathrm{L}^{-1}$ in solid medium. The UFSC-PT24 and UFSC-Sc124 isolates have increased copper-resistance in liquid medium. The higher production of extracellular pigment was detected in UFSC-Pt1 16 cultures. The UFSC-Pt116 and UFSC-PT24 isolates showed higher resistance for copper and produced higher mycelium biomass than the other isolates. In this way, the isolates UFSG-Pt116 and UFSC-PT24 can be important candidates to survive in coppercontaminated areas, and can show important role in plants symbiosis in these contaminated sites.
\end{abstract}

Key words: ectomycorrhizal fungus, copper-resistance, Pisolithus microcarpus, Pisolithus sp., Scleroderma sp., Suillus sp.

\section{Introduction}

Environment contamination with heavy metals has increased over the years. The composition of fungi, plants and microbial activity of the soil can be negatively influenced by the environment contamination due to the processes of mining, smelting, processing and manufacturing of metals and their sub-products (Colpaert, 2008; Rühling and Söderstrom, 1990). One of the ways to reduce the impact caused by these activities on the soils is the use of bioremediation process which aims to use metabolism of microorganisms for elimination or reduction of pollutants in the environment to acceptable levels (Gadd, 2007).
Many ectomycorrhizal fungi that show resistance to heavy metals, together with the use of plants, can be useful in bioremediation of contaminated areas (Perotto and Martino, 2001; Van Tichelen et al., 2001). These microorganisms can mobilize or exclude metals from their fungal structures located in the root system of plants by establishing links with peptides, organic acids and cell wall polymers such as chitin and melanin (Galli et al., 1993; Zheng et al., 2009). The production of melanin has been considered the main mechanism of tolerance to heavy metals (Gadd, 1993; Martino et al., 2003), as it can act in the extracellular precipitation in the adsorption of heavy metals, preventing their action on fungi (Bellion et al., 2006; Forgaty and

Send correspondence to R. Andreazza. Center of Engineering, Federal University of Pelotas, Rua Almirante Barroso 1734, 96010-280 Pelotas, RS, Brazil. E-mail: robsonandreazza@yahoo.com.br. 
Tobin, 1996; Gadd, 2004). Apart from this, the ectomycorrhizal can exert nutritional and non-nutritional effects which facilitate the vegetal growth, important for re-vegetation of degraded areas, including areas contaminated with metals and salts (Khan, 2001; Wang et al., 2011). However, to be used in programs of soil bioremediation, exerting beneficial effects for the host plants in condition of high concentration of heavy metals it is necessary to assess the impact of these inorganic contaminants on these fungi.

Heavy metals, when in high concentration in the environment can negatively impact the development of the ectomycorrhizal fungi (Bell et al., 1988; Grazziotti et al., 2001). Studies in pure culture medium can be an important tool to assess the relation between ectomycorrhizal fungi and heavy metals. For the culture of fungi in laboratory conditions, both solid and liquid medium can influence the tolerance to the metals due to the complexity of the heavy metals in the matrix of the subtract, altering its availability; or agar itself can also contain heavy metals (Blaudez et al., 2000; Gadd, 1993). Hartley et al. (1997) also reported that the mycelium of basidiomycetes does not develop completely in liquid media and this can affect the reaction of the organism with the heavy metals. Colpaert and Van Assche (1988) indicate that a lower tolerance of ectomycorrhizal fungi to heavy metals, causing variation in tolerance of ectomycorrhizal genera when adding the same doses of metal in solid media. Thus, $\mathrm{CL}_{50}$ values were found (concentration to reduce $50 \%$ of growth) ten times less in liquid media than in solid media, in species belonging to the genera Suillus, Scleroderma and Pisolitus (Blaudez et al., 2000; Colpaert and Van Assche, 1988; Martino et al., 2000). This variation in $\mathrm{CL}_{50}$ of ectomycorrhizal fungi among solid and liquid media indicates the need for using these two types of media to compare the tolerance of ectomycorrhizal fungi to heavy metals. However, it is necessary to know the potential resistance of the ectomycorrhizal fungi for its applicability in the environment and production in the laboratory.

Faced with increasing soil contamination by copper in large areas of processing this chemical component, selecting copper-resistant ectomycorrhizal fungi becomes an important characteristic to be used in bioremediation programs. So, ectomycorrhizal fungi that are resistant to copper can be an efficient alternative for the bioremediation of copper-contaminated environments. Therefore, this study aimed to assess the copper-resistance of four ectomycorrhizal isolates of distinct genera, Pisolithus, Scleroderma and Suillus, in solid and liquid media.

\section{Materials and Methods}

For characterizing the influence of copper on ectomycorrhizal fungi growth, experiments in solid and liquid Melin-Norkrans Modified (MNM) media (Marx, 1969) were performed. The concentration of added copper varied according to the media used, based on results of Colpaert and Van Assche (1998), which indicate lower tolerance of ectomycorrhizal fungi in liquid medium. To avoid precipitation of $\mathrm{Cu}$, the medium MNM was prepared according to Grazziotti et al. (2001).

The ectomycorrhizal isolates used were: Suillus sp. (UFSM RA 2.8), P. microcarpus (UFSC-Pt116); Pisolithus sp. (UFSC-Pt24) and Scleroderma sp. (UFSC-Sc124). The isolates of the genera Pisolithus and Scleroderma sp. were obtained from the Federal University of Santa Catarina. The isolate Suillus sp. was collected at the State Foundation for Agricultural Research (FEPAGRO-FLORESTAS, RS), isolated and identified according to Brundrett et al. (1996). The sporocarps were collected from the forestry, identified, higienized and saved in the properly paper bags with the identification and carried out to the Laboratory for further analysis. The sporocarps were than cleaned with alcohol $70 \%$ in the flow chamber, then broken in half and were withdrawn a portion of the mycelium and placed for incubation in Petry dishes containing Hagen medium $(0.5 \mathrm{~g}$ of $\mathrm{NH}_{4} \mathrm{Cl} ; 0.5 \mathrm{~g}$ of $\mathrm{KH}_{2} \mathrm{PO}_{4} ; 0.5 \mathrm{~g}$ of $\mathrm{MgSO}_{4} .7 \mathrm{H}_{2} \mathrm{O} ; 5.0 \mathrm{~g}$ of glicose; $50 \mathrm{ug}$ of thiamine; $0.5 \mathrm{~mL}$ of $\mathrm{FeCl}_{3} ; 10 \mathrm{~g}$ of agar in $1000 \mathrm{~mL}$ of distilled water). The plates were incubated and the no contaminated mycelium was transferred to Petri dishes with medium MNM. After isolation, the fungi were processed in the laboratory using aseptic techniques for the multiplication of the ectomycorrhizal fungi (Brundrett $e t$ al., 1996). After that, the characteristics of the sporocarps, mycelium and spores were then identified.

For the experiment with the solid medium MNM, the experimental unit was a Petri dish, containing $20 \mathrm{~mL}$ of solid medium MNM. The inoculation of ectomycorrhizal was realized with three discs, $10 \mathrm{~mm}$ in diameter, of mycelium taken from the edges of the colonies grown in Petri dishes during 30 days with solid medium MNM, in $\mathrm{pH} 4.8$. After the inoculation the dishes were incubated at $28{ }^{\circ} \mathrm{C}$ during 30 days. The test was conducted in complete randomizing way with seven repetitions. The tested doses of copper were $0.0 ; 0.25 ; 0.5 ; 0.75 ; 1.0$ and $1.25 \mathrm{mmol} \mathrm{L}^{-1}$, corresponding to $0,16,32,48,64$ and $80 \mathrm{mg} \mathrm{L}^{-1}$, respectively.

To assess the behaviour of ectomycorrhizal fungi in the liquid medium, the experimental unit was an erlenmeyer flask $(250 \mathrm{~mL})$, with $25 \mathrm{~mL}$ of medium MNM amended with $\mathrm{Cu}$ and it was inoculated the fungi as described above. The doses of copper were $0.0 ; 0.32 ; 0.64$ and $0.96 \mathrm{mmol} \mathrm{L}^{-1}$, corresponding to $0,20,40$ and $60 \mathrm{mg} \mathrm{L}^{-1}$, respectively. The quantities of copper were different from that used in the solid medium, according to Colpaert and Van Assche (1998). The experiment was completely randomized with seven repetitions. After the inoculation the Erlenmeyers flasks were incubated at $28^{\circ} \mathrm{C}$ during 30 days without agitation.

The variables analysed in the test were: dry mass of fungal mycelia, mean diameter of the mycelium and total production of extracellular pigments. The total production 
of extracellular pigments was obtained by the expression of light absorbance of the visible $\lambda=350 \mathrm{~mm}$ according to Grazziotti et al. (2001). To determine extracellular pigments the solid MNM medium was heated and diluted five times to be maintained in liquid phase and then filtered through filter paper (Whatman \# 42) to retain fungal biomass. The fungal mycelium retained on the filter paper was used to determine the mycelium dry mass, which was dried at $60{ }^{\circ} \mathrm{C}$ until constant weight. The determination of production of extracellular pigments in liquid was directly in the culture medium and the fungal mycelium was removed with forceps and taken to the oven for drying and further dry mass determination.

The variables analysed were subjected to variance analysis and their media were compared by the Tukey test and regression equations were adjusted for the applied copper doses based on the significance levels higher than $95 \%$
( $\mathrm{p} \leq 0,05$ ), using the statistic program SISVAR (Ferreira, 2008). The variables also were subjected to multivariate group analysis (Cluster) through Euclidian distance using the program STATISTICA (1996).

\section{Results}

\section{Copper-resistance and pigment production}

The results obtained in solid culture medium exhibited significant reduction in the diameter of the mycelium only for the isolate UFSM RA 2.8 with increasing doses of copper (Table 1). Significant reduction in the pigment values is also observed $(\lambda=350 \mathrm{~nm})$, for the isolate UFSM RA 2.8 when added $125 \mathrm{mmol} \mathrm{kg}^{-1}\left(80 \mathrm{mg} \mathrm{kg}^{-1}\right)$ of copper and significant increase for the isolates UFSC-Pt116 and UFSC-Pt24 with increasing doses of copper. No significant

Table 1 - Average diameter of mycelium, dry mass of fungal mycelia (MSMF) and pigmentation at $\lambda=350 \mathrm{~nm}$ of the isolates UFSM RA 2.8, UFSC-Pt116, UFSC-Pt24 and UFSC-Sc124 subjected to growth in different doses of copper in solid culture medium MNM.

\begin{tabular}{|c|c|c|c|c|}
\hline \multirow[t]{2}{*}{ Copper doses $\left(\mathrm{mmol} \mathrm{kg}^{-1}\right)$} & \multicolumn{4}{|c|}{ Ectomycorrhizal Isolates } \\
\hline & UFSM RA2.8 & UFSC-Pt116 & UFSC-Pt24 & UFSC-Sc124 \\
\hline & \multicolumn{4}{|c|}{ Mycelium diameter $(\mathrm{cm})$} \\
\hline 0.00 & $5.37 * \mathrm{aA}$ & $4.91 \mathrm{aA}$ & $6.20 \mathrm{aA}$ & $5.75 \mathrm{aA}$ \\
\hline 0.25 & $3.50 \mathrm{abB}$ & $4.90 \mathrm{aA}$ & $6.35 \mathrm{aA}$ & $5.59 \mathrm{aA}$ \\
\hline 0.50 & $2.75 \mathrm{abB}$ & $5.70 \mathrm{aA}$ & $6.47 \mathrm{aA}$ & $5.46 \mathrm{aA}$ \\
\hline 0.75 & $2.79 \mathrm{abB}$ & $5.73 \mathrm{aA}$ & $5.48 \mathrm{aA}$ & $5.70 \mathrm{aA}$ \\
\hline 1.00 & $2.40 \mathrm{bB}$ & $4.91 \mathrm{aA}$ & $5.45 \mathrm{aA}$ & $6.40 \mathrm{aA}$ \\
\hline 1.25 & $2.22 \mathrm{bB}$ & $4.82 \mathrm{aA}$ & $5.01 \mathrm{aA}$ & $4.62 \mathrm{aA}$ \\
\hline \multirow[t]{2}{*}{ CV (\%) } & 13.06 & & & \\
\hline & \multicolumn{4}{|c|}{$\operatorname{MSMF}(\mathrm{g})$} \\
\hline 0.00 & $0.103 \mathrm{aA}$ & $0.125 \mathrm{aA}$ & $0.149 \mathrm{aA}$ & $0.047 \mathrm{aB}$ \\
\hline 0.25 & $0.138 \mathrm{aA}$ & $0.126 \mathrm{aA}$ & $0.106 \mathrm{aA}$ & $0.071 \mathrm{aB}$ \\
\hline 0.50 & $0.122 \mathrm{aA}$ & $0.144 \mathrm{aA}$ & $0.112 \mathrm{aA}$ & $0.062 \mathrm{aB}$ \\
\hline 0.75 & $0.115 \mathrm{aA}$ & $0.134 \mathrm{aA}$ & $0.143 \mathrm{aA}$ & $0.065 \mathrm{aB}$ \\
\hline 1.00 & $0.111 \mathrm{aA}$ & $0.109 \mathrm{aA}$ & $0.132 \mathrm{aA}$ & $0.070 \mathrm{aB}$ \\
\hline 1.25 & $0.090 \mathrm{aB}$ & $0.090 \mathrm{aB}$ & $0.137 \mathrm{aA}$ & $0.039 \mathrm{aB}$ \\
\hline \multirow[t]{2}{*}{ CV (\%) } & 2.87 & & & \\
\hline & \multicolumn{4}{|c|}{ Pigmentation $(\lambda=350 \mathrm{~nm})$} \\
\hline 0.00 & $0.000 \mathrm{bB}$ & $0.055 \mathrm{bA}$ & $0.029 \mathrm{bA}$ & $0.000 \mathrm{aB}$ \\
\hline 0.25 & $0.106 \mathrm{aAB}$ & $0.211 \mathrm{abA}$ & $0.018 \mathrm{bB}$ & $0.035 \mathrm{aB}$ \\
\hline 0.50 & $0.120 \mathrm{aAB}$ & $0.217 \mathrm{aA}$ & $0.048 \mathrm{abB}$ & $0.017 \mathrm{aB}$ \\
\hline 0.75 & $0.140 \mathrm{aAB}$ & $0.253 \mathrm{aA}$ & $0.171 \mathrm{aA}$ & $0.000 \mathrm{aB}$ \\
\hline 1.00 & $0.151 \mathrm{aA}$ & $0.133 \mathrm{abA}$ & $0.103 \mathrm{aA}$ & $0.000 \mathrm{aB}$ \\
\hline 1.25 & $0.042 \mathrm{bB}$ & $0.159 \mathrm{abA}$ & $0.119 \mathrm{aA}$ & $0.000 \mathrm{aB}$ \\
\hline 0.00 & $0.000 \mathrm{bB}$ & $0.055 \mathrm{bA}$ & $0.029 \mathrm{bA}$ & $0.000 \mathrm{aB}$ \\
\hline CV (\%) & 6.51 & & & \\
\hline
\end{tabular}

*Means followed by the same lowercase letter in the column and uppercase letter in the line, inside each variable, are not different among them by the Tukey test at $5 \%$ of error probability $(\mathrm{p}<0.05)$.

***Determined in the culture medium MNM. 
alteration in the fungal mycelium mass of the analysed isolates in the different copper doses was observed.

In the solid culture medium the isolates UFSC-Pt116, UFSM-Pt24 and UFSC-Sc124 produced higher average diameter of mycelium than the isolate UFSM RA 2.8 in the different copper doses (Table 1). The isolate UFSC-Sc124 showed smaller dry mass of the fungal mycelium than the other fungi, when applied to concentrations up to $1.0 \mathrm{mmol}$ $\mathrm{L}^{-1}$ of copper, while in the higher dose $\left(1.25 \mathrm{mmol} \mathrm{L}^{-1}\right)$ the isolate UFSC-Pt24 was significantly superior to the others (Table 1). The highest pigment produced was obtained for the isolates UFSC-Pt116 and UFSC-Pt24 with the increasing doses of copper (Table 1).

In the liquid culture medium, the four studied isolates showed significant reduction in the average diameter of the mycelium, dry mass of the fungal mycelium and in the pigment production (expressed in units, with the absorbance at $350 \mathrm{~nm}$ ) in the dose $0.96 \mathrm{mmol} \mathrm{L}^{-1}$ of copper (Table 2). In the liquid medium the isolates UFSC-Pt116, UFSC-Pt 24 and UFSC-Sc124 exhibited higher average diameter of the fungal mycelium and pigment production than the isolate UFSM RA 2.8 until $0.64 \mathrm{mmol} \mathrm{L}^{-1}$ of copper concentration (Table 2). The production of fungal mycelium dry mass of the isolate UFSC-Pt116 is equivalent to the UFSC-Pt24 which was significantly superior to the other isolates, in the copper concentrations up to the copper dose of $0.64 \mathrm{mmol}$
$\mathrm{L}^{-1}$ (Table 2). These results indicate that in the liquid medium, the negative effect of $\mathrm{Cu}$ on the growth of fungi seems to have been higher than in solid medium, even with application of smaller doses of copper.

\section{Relationship and tendencies of the copper-resistance}

The analysis of main components of copper-resistance showed varied responses on the fungal growth in the solid medium, depending on the ectomycorrhizal isolate and metal concentration (Figure 1). The isolates UFSC-PT116 and UFSM RA 2.8, in the concentration of $0.5 \mathrm{mmol} \mathrm{L}^{-1}$ of copper, it resulted in a higher growth of mycelia mass and for the isolate UFSC-SC124, this higher growth was observed when the copper concentration used was $1.25 \mathrm{mmol} \mathrm{L}^{-1}$. However, the copper concentrations in the solid medium did not affect significantly the dry mass production of the mycelia in the isolate UFSC-PT24 (Figure $1 b$ ). Thus, the analysis of the main components showed a more sensitive technique than the conventional used to assess the influence of metals on the growth of fungal isolates and indicates copper-resistance of the isolate.

In the Figure 2, it was exhibited that the fungal isolates in the liquid medium increased the mycelium growth when exposed to copper concentration of $0.32 \mathrm{mmol} \mathrm{L}^{-1}$. The copper concentrations 0.64 and $0.92 \mathrm{mmol} \mathrm{L}^{-1}$ pro-

Table 2 - Diameter of the mycelium, dry mass of fungal mycelia (MSMF) and medium pigmentation at $\lambda=350 \mathrm{~nm}$ of the isolates UFSM RA 2.8, UFSC-Pt116, UFSC-Pt24 and UFSC-Sc124 subjected to growth in different doses of copper in liquid culture medium MNM.

\begin{tabular}{|c|c|c|c|c|}
\hline \multirow[t]{2}{*}{ Copper doses $\left(\mathrm{mmol} \mathrm{L}^{-1}\right)$} & \multicolumn{4}{|c|}{ Ectomycorrhizal Isolates } \\
\hline & UFSM RA2.8 & UFSC-Pt116 & UFSC-Pt24 & UFSC-Sc124 \\
\hline & \multicolumn{4}{|c|}{ Mycelium diameter $(\mathrm{cm})$} \\
\hline 0.00 & $2.82 * \mathrm{aB}$ & $4.50 \mathrm{aA}$ & $5.03 \mathrm{aA}$ & $4.68 \mathrm{aA}$ \\
\hline 0.32 & $1.49 \mathrm{aB}$ & $4.64 \mathrm{aA}$ & $4.39 \mathrm{aA}$ & $5.05 \mathrm{aA}$ \\
\hline 0.64 & $1.24 \mathrm{aB}$ & $4.69 \mathrm{aA}$ & $4.76 \mathrm{aA}$ & $4.77 \mathrm{aA}$ \\
\hline 0.96 & $0.00 \mathrm{bA}$ & $0.00 \mathrm{bA}$ & $0.00 \mathrm{bA}$ & $0.00 \mathrm{bA}$ \\
\hline \multirow[t]{2}{*}{ CV (\%) } & 22.04 & & & \\
\hline & \multicolumn{4}{|c|}{$\operatorname{MSMF}(\mathrm{g})$} \\
\hline 0.00 & $0.167 \mathrm{aAB}$ & $0.205 \mathrm{aAB}$ & $0.288 \mathrm{aA}$ & $0.099 \mathrm{aB}$ \\
\hline 0.32 & $0.095 \mathrm{aA}$ & $0.166 \mathrm{aA}$ & $0.210 \mathrm{aA}$ & $0.091 \mathrm{aB}$ \\
\hline 0.64 & $0.046 \mathrm{abB}$ & $0.123 \mathrm{abA}$ & $0.180 \mathrm{aA}$ & $0.087 \mathrm{aB}$ \\
\hline 0.96 & $0.000 \mathrm{bA}$ & $0.000 \mathrm{bA}$ & $0.000 \mathrm{bA}$ & $0.000 \mathrm{bA}$ \\
\hline \multirow[t]{2}{*}{ CV (\%) } & 7.62 & & & \\
\hline & \multicolumn{4}{|c|}{ Pigmentation $(\lambda=350 \mathrm{~nm})$} \\
\hline 0.00 & $0.144 \mathrm{aB}$ & $0.616 \mathrm{aA}$ & $0.574 \mathrm{aA}$ & $0.439 \mathrm{aA}$ \\
\hline 0.32 & $0.056 \mathrm{aB}$ & $0.628 \mathrm{aA}$ & $0.526 \mathrm{aA}$ & $0.444 \mathrm{aAB}$ \\
\hline 0.64 & $0.042 \mathrm{aB}$ & $0.478 \mathrm{aA}$ & $0.489 \mathrm{aA}$ & $0.433 \mathrm{aA}$ \\
\hline 0.96 & $0.000 \mathrm{bA}$ & $0.000 \mathrm{bA}$ & $0.000 \mathrm{bA}$ & $0.000 \mathrm{bA}$ \\
\hline CV (\%) & 16.86 & & & \\
\hline
\end{tabular}

*Means followed by the same lowercase letter in the column and uppercase letter in the line, inside each variable, are not different among them by the Tukey test at $5 \%$ of error probability $(\mathrm{p}<0.05)$.

**Determined in the culture medium MNM. 

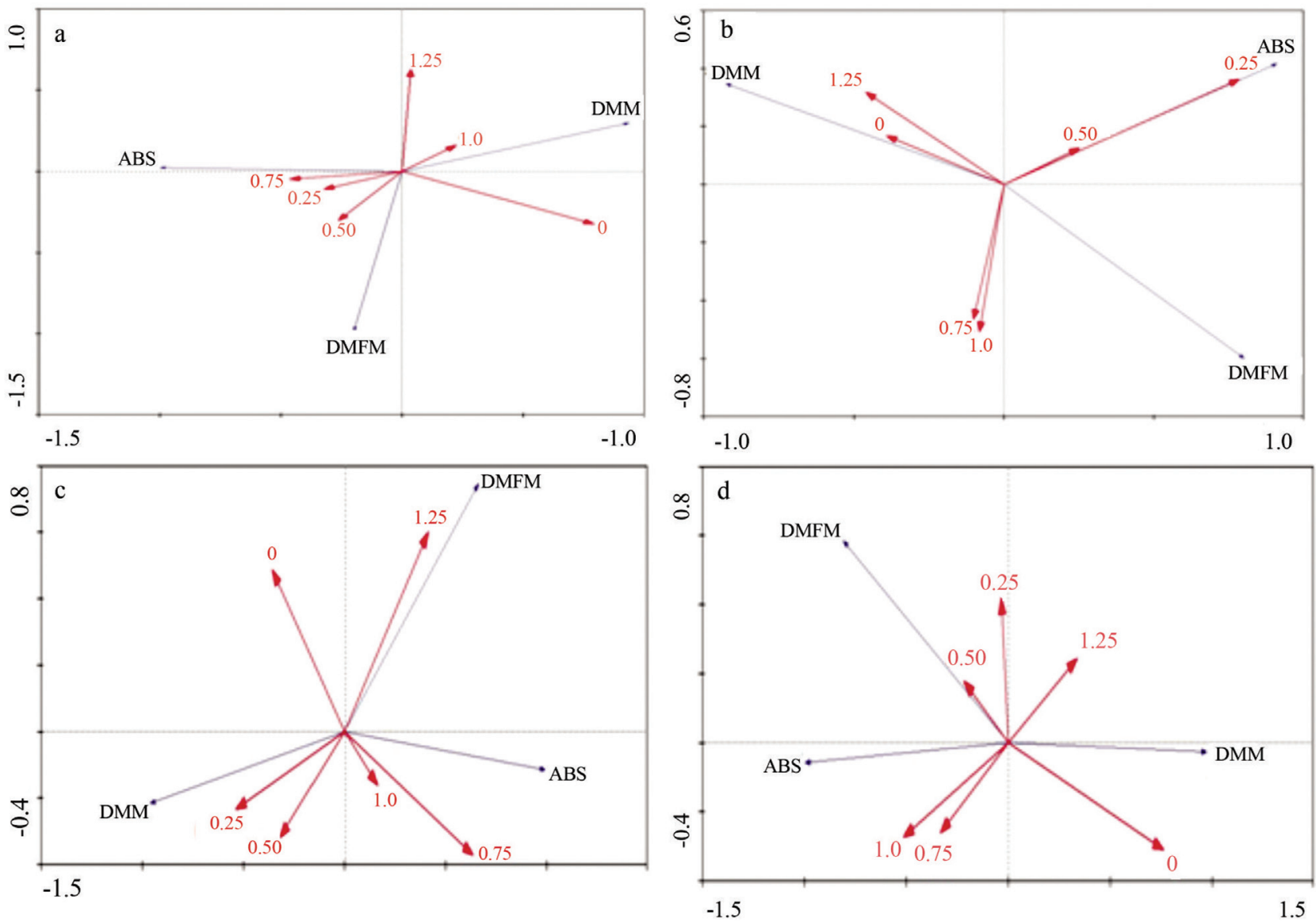

Figure 1 - Graphic representation of the analysis of main components (PCA) relating the 1 and 2 dimensions to the growth of ectomycorrhizal isolates (a) UFSC-PT116, (b) UFSC-PT24, (c) UFSC-SC124 and (d) UFSM RA 2.8, in different copper concentrations in solid medium. DMM: average diameter of mycelia (mm); DMFM: dry mass of fungal mycelia (g); ABS: pigmentation at $\lambda=350 \mathrm{~nm}$ (ABS).

moted an inhibition of fungal growth of the isolates, except for the isolate UFSC-SC124 whose copper concentration $0.64 \mathrm{mg} \mathrm{L}^{-1}$ promoted in the mycelium growth, similar results to that in the $0.32 \mathrm{mg} \mathrm{L}^{-1}$ of copper concentration.

The data presented in the Figures 1 and 2 showed the variation in the stimulatory effect of determined copper concentration in the growth of fungal isolates in liquid and solid culture media. The highest production of mycelia biomass of the ectomycorrhizal isolates may have occurred due to mechanisms of excretion of organic molecules, especially of di- and tri-carboxylic acids, which produce turbidity of the medium.

\section{Regression analysis of the copper-resistance}

The regression analysis showed that in solid medium the growth in diameter of the isolates UFSC-Pt116, UFSCPt24 and UFSC-Sc124 was stimulated up to the doses 0.61, 0.08 and $0.35 \mathrm{mmol} \mathrm{kg}^{-1}$ of $\mathrm{Cu}$, decrease occurring from these doses (Table 3). The isolate UFSC-Pt24 showed increase in diameter of mycelium up to the copper dose $0.25 \mathrm{mmol} \mathrm{L}^{-1}$, while from this dose the copper started having a deleterious effect on the growth of this fungus. The isolate UFSM RA 2.8 showed different behaviour compared to the other isolates while the reduction in its diameter occurred with the increase of the copper concentration in the solid and liquid media (Tables 3 and 4). In liquid medium (Table 4) the isolates UFSC-Pt116, UFSC-Pt24 and UFSC-Sc124 showed growth in diameter similar to the copper presence in the solid culture medium.

The isolates UFSM RA 2.8, UFSC-Pt116 and UFSC-Sc124 grown in the solid culture medium increased the dry matter production up to the doses of $0.46 \mathrm{mmol} \mathrm{L}^{-1}$, $0.54 \mathrm{mmol} \mathrm{L}^{-1}$ and $0.63 \mathrm{mmol} \mathrm{L}^{-1}$ of $\mathrm{Cu}$, respectively (Table 3). The isolate UFSC-Pt24 reduced initially the dry matter of the mycelium to the copper concentration of $0.56 \mathrm{mmol} \mathrm{L}^{-1}$; however, after this dose, the isolate increased the dry matter of the mycelium, indicating a possible activation of tolerance mechanisms to the copper in high doses (Table 3). Due to the dry mass values and their behaviour in different copper doses, the analysis of $\mathrm{CL}_{50}$ of these fungi, it was verified similar values among the isolates UFSM RA 2.8, UFSC-Pt116 and UFSC-Sc124 (1.61 $\mathrm{mmol} \mathrm{L}^{-1}, 1.44 \mathrm{mmol} \mathrm{L}^{-1}$ and $1.47 \mathrm{mmol} \mathrm{L}^{-1}$, respectively). It was not possible to determine the $\mathrm{CL}_{50}$ of the iso- 
late UFSC-Pt24 due to its standard growth comparing to the copper doses.

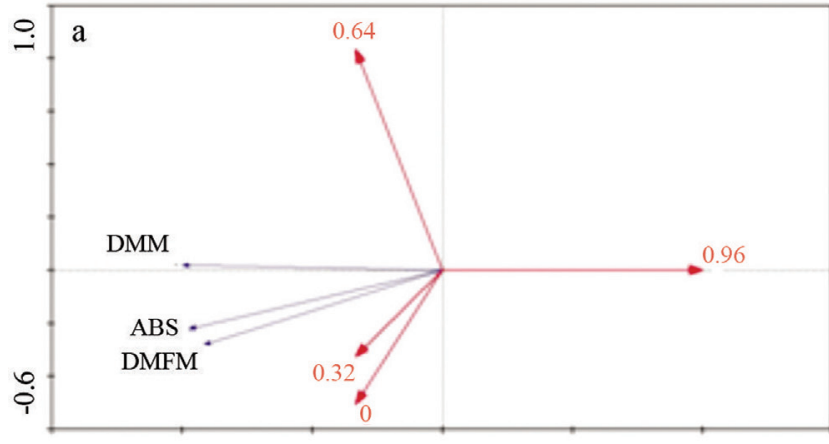

$-1.5$

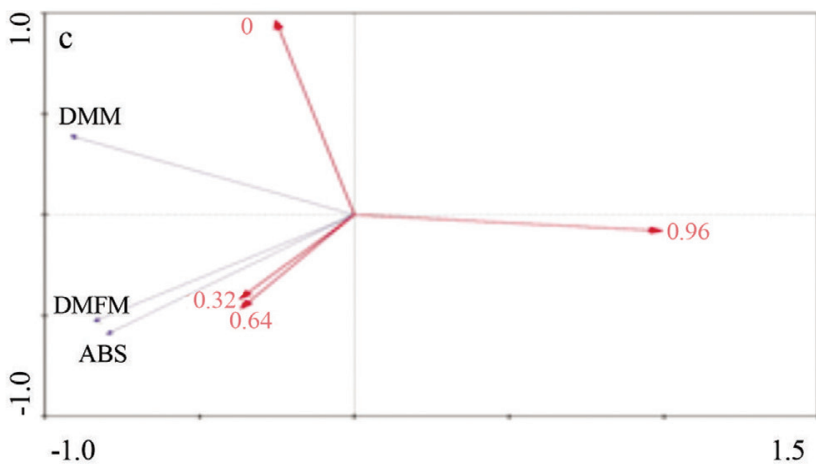

In the liquid medium, the isolates showed a different behaviour in relation to dry mass production in the solid
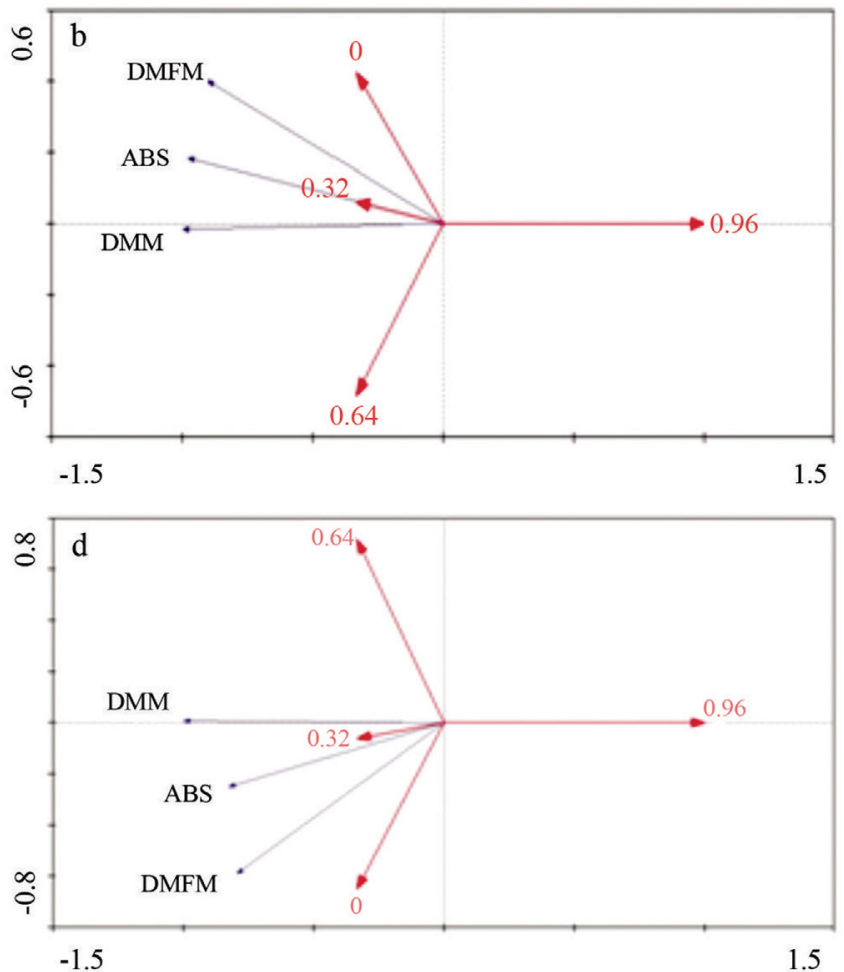

Figure 2 - Relations between the main components (PCA) relating the dimensions 1 and 2 concerning the growth of ectomycorrhizal isolates (a) UFSC PT 116, (b) UFSC PT 24, (c) UFSC SC 124 and (d) UFSM RA 2.8, in different copper concentrations in liquid medium. DMM: average diameter of mycelia (mm); DMFM: dry mass of fungal mycelia (g); ABS: pigmentation at $\lambda=350 \mathrm{~nm}$.

Table 3 - Regression equations of the parameters average diameter of mycelia (DMM), dry mass of mycelia $(\mathrm{MSMF})$, pigmentation at $\lambda=350 \mathrm{~nm}(\mathrm{ABS})$ and specific pigmentation at $\lambda=350 \mathrm{~nm}$ (ABS esp), $\mathrm{r}^{2}$ e $\mathrm{CL}_{50}$ of the isolates UFSM RA 2.8, UFSC-Pt116, UFSC-Pt24 and UFSC-Sc124 subjected to growth in different doses of copper in solid culture medium MNM.

\begin{tabular}{|c|c|c|c|c|}
\hline Isolates & Parameters & Equations & $r^{2}$ & $\mathrm{CL}_{50}$ \\
\hline \multirow[t]{4}{*}{ UFSC-Pt116 } & $\mathrm{DMM}(\mathrm{cm})$ & $y=-2.1136 x^{2}+2.5682 x+4.8549$ & 0.8755 & \multirow{4}{*}{1.44} \\
\hline & $\operatorname{MSMF}(\mathrm{g})$ & $y=-0.0812 x^{2}+0.0754 x+0.1224$ & 0.9633 & \\
\hline & $\mathrm{ABS}(\mathrm{nm})^{*}$ & $y=-0.3382 x^{2}+0.4806 x+0.0698$ & 0.8894 & \\
\hline & ABS esp $\left(\mathrm{nm} \mathrm{g}^{-1}\right)$ & $Y=-1.5943 x^{2}+2.8103 x+0.5998$ & 0.8365 & \\
\hline \multirow[t]{4}{*}{ UFSC-Pt24 } & $\mathrm{DMM}(\mathrm{cm})$ & $y=-1.0136 x^{2}+0.1678 x+6.3021$ & 0.8421 & \multirow{4}{*}{ nd } \\
\hline & $\operatorname{MSMF}(\mathrm{g})$ & $y=0.1008 x^{2}-0.1002 x+0.1406$ & 0.7221 & \\
\hline & ABS (nm) & $Y=0.0149 x^{2}+0.0698 x+0.0161$ & 0.8334 & \\
\hline & ABS esp $\left(\mathrm{nm} \mathrm{g}^{-1}\right)$ & $y=-2.4863 x^{2}+0.833 x+0.0978$ & 0.8048 & \\
\hline \multirow[t]{4}{*}{ UFSC-SC124 } & $\mathrm{DMM}(\mathrm{cm})$ & $y=-1.2929 x^{2}+0.9132 x+5.6216$ & 0.8725 & \multirow{4}{*}{1.47} \\
\hline & $\operatorname{MSMF}(\mathrm{g})$ & $y=-0.052 x^{2}+0.0604 x+0.048$ & 0.903 & \\
\hline & ABS (nm) & $y=0.0035 x^{2}-0.0232+0.0213$ & 0.8228 & \\
\hline & ABS esp $\left(\mathrm{nm} \mathrm{g}^{-1}\right)$ & $y=0.3241 x^{2}-0.8196 x+0.5025$ & 0.8365 & \\
\hline \multirow[t]{4}{*}{ UFSM RA 2.8} & $\mathrm{DMM}(\mathrm{cm})$ & $y=2.8236 x^{2}-5.7017 x+5.1163$ & 0.9346 & \multirow{4}{*}{1.61} \\
\hline & $\operatorname{MSMF}(\mathrm{g})$ & $y=-0.0613 x^{2}+0.0658 x+0.1204$ & 0.9504 & \\
\hline & ABS (nm) & $y=-0.3103 x^{2}+0.4295 x+0.0024$ & 0.9019 & \\
\hline & ABS esp $\left(\mathrm{nm} \mathrm{g}^{-1}\right)$ & $y=-2.4863 x^{2}+3.5615 x+0.0152$ & 0.8896 & \\
\hline
\end{tabular}

$\mathrm{Nd}=$ not determined

* Determined in the culture medium MNM. 
medium (Table 4). The reduction of the dry mass production of the fungi UFSM RA 2.8, UFSC-Pt 116 and UFSC$\mathrm{Pt} 24$ were proportional to the addition of copper in the liquid medium while the isolate UFSC-Sc124 initially showed tendency to increase the production of dry matter; however, it reduced its growth in the higher copper doses (Table 4). The $\mathrm{Cl}_{50}$ values found were similar among the isolates UFSC-Pt116, UFSC-Pt24 and UFSC-Sc124 (0.67; 0.65 and $0.77 \mathrm{mmol} \mathrm{L}^{-1}$ of copper, respectively); however higher in relation to the UFSM RA $2.8\left(0.39 \mathrm{mmol} \mathrm{L}^{-1}\right.$ of copper $)$, which reduced the dry matter with the increase of copper doses (Table 4).

The isolates UFSM RA 2.8 and UFSC-Pt116 showed higher extracellular pigment production measured by the absorbance at $350 \mathrm{~nm}$, compared to the other fungi tested in the solid medium, while the extracellular pigment production grew with the addition of copper in the medium up to 0.71 and $0.88 \mathrm{mmol} \mathrm{kg}^{-1}$, respectively (Table 3 ). The isolate UFSC-Pt24 showed increase in the pigment production with the increase of copper doses in the medium, while the isolate UFSC-Sc124 showed reduction in pigment production with the increase of copper concentration in the medium (Table 3). This may has occurred due to the white colour of the fungal mycelium.

In the liquid medium (Table 4), the isolates UFSM RA 2.8 and UFSC-Pt116 exhibited the same tendency of total and specific pigment production as in the solid medium, while the increase in the total production was up to the copper doses of 0.23 and $0.21 \mathrm{mmol} \mathrm{L}^{-1}$, respectively. The be- haviour of the isolate UFSC-Pt24 in the liquid medium in the pigment production was different from that shown in the solid medium. Here, the isolate showed a trend to produce a higher amount of total pigment up to the copper dose of $0.36 \mathrm{mmol} \mathrm{L}^{-1}$ and reduce in the higher concentrations of this element, while the specific pigment production showed a similar trend to the total pigment production. The isolate UFSC-Sc124 also showed difference in the total and specific pigment production in liquid medium when compared to the production in solid medium, showing increase in the total pigment production up to the copper dose of $0.31 \mathrm{mmol} \mathrm{L}^{-1}$ (Table 4).

\section{Discussion}

Current studies about copper-resistance and microorganisms such as bacteria have shown good results for the bioremediation of environments polluted with copper (Andreazza et al., 2010, 2011). Also, ectomycorrhizal fungi have been studied for this purpose and showed high efficiency (Wang et al., 2011). In our study, the resistance of different isolates of ectomycorrhizal fungi symbiosisefficient was assayed, in different copper concentrations for subsequent use of these fungi for the bioremediation of copper contaminated areas. The isolates showed different behaviours with the different copper concentration and different media types. This difference in responses of ectomycorrhizal fungi to metals has been reported (Colpaert, 2008; Johansson et al., 2008; Sharples et al., 2001) and indicated

Table 4 - Regression equations of the parameters: average diameter of mycelia (DMM), dry mass of mycelia (MSMF), pigmentation at $\lambda=350 \mathrm{~nm}(\mathrm{ABS})$ and specific pigmentation at $\lambda=350 \mathrm{~nm}$ (ABS esp), $\mathrm{r}^{2}$ e $\mathrm{CL}_{50}$ of the isolates UFSM RA 2.8, UFSC-Pt116, UFSC-Pt24 and UFSC-Sc124 subjected to growth in different copper doses in liquid culture medium MNM.

\begin{tabular}{|c|c|c|c|c|}
\hline Isolates & Parameters & Equations & $r^{2}$ & $\mathrm{CL}_{50}$ \\
\hline \multirow[t]{4}{*}{ UFSC-Pt116 } & $\operatorname{DMM}(\mathrm{cm})$ & $y=-11.798 x^{2}+7.1207 x+4.2699$ & 0.9323 & \multirow{4}{*}{0.68} \\
\hline & $\operatorname{MSMF}(\mathrm{g})$ & $y=-0.2053 x^{2}+0.0084 x+0.2011$ & 0.9878 & \\
\hline & $\mathrm{ABS}(\mathrm{nm}) *$ & $y=-1.1691 x^{2}+0.4944 x+0.6094$ & 0.9967 & \\
\hline & $\operatorname{ABS} \operatorname{esp}\left(\mathrm{nm} \mathrm{g}^{-1}\right)$ & $y=-11.664 x^{2}+8.34894 x+2.8914$ & 0.9525 & \\
\hline \multirow[t]{4}{*}{ UFSC-Pt24 } & DMM & $y=-10.04 x^{2}+5.0395 x+4.7226$ & 0.8885 & \multirow{4}{*}{0.66} \\
\hline & MSMF & $y=-0.250 x^{2}-0.0389 x+0.2777$ & 0.903 & \\
\hline & $\mathrm{ABS}(\mathrm{nm})$ & $y=-1.0781 x^{2}+0.486 x+0.5502$ & 0.9502 & \\
\hline & ABS esp $\left(\mathrm{nm} \mathrm{g}^{-1}\right)$ & $y=-7.8806 x^{2}+5.719 x+1.9054$ & 0.9248 & \\
\hline \multirow[t]{4}{*}{ UFSC-SC124 } & DMM & $Y=-12.549 x^{2}+7.5719 x+4.488$ & 0.9581 & \multirow{4}{*}{0.77} \\
\hline & MSMF & $y=-0.1911 x^{2}+0.0886 x+0.0953$ & 0.9439 & \\
\hline & $\operatorname{ABS}(\mathrm{nm})$ & $y=-1.0694 x^{2}+0.6117 x+0.4188$ & 0.9422 & \\
\hline & ABS esp & $y=-12.825 x^{2}+8.112 x+4.2541$ & 0.9419 & \\
\hline \multirow[t]{4}{*}{ UFSM RA 2.8} & DMM & $y=-2.7242 x+2.6945$ & 0.9459 & \multirow{4}{*}{0.39} \\
\hline & MSMF & $y=0.0643 x^{2}-0.2336 x+0.1661$ & 0.9983 & \\
\hline & $\mathrm{ABS}(\mathrm{nm})$ & $\mathrm{y}=0.1142 \mathrm{x}^{2}+0.2488 \mathrm{x}+0.1388$ & 0.9511 & \\
\hline & ABS esp $\left(\mathrm{nm} \mathrm{g}^{-1}\right)$ & $y=-1.4572 x^{2}+0.6814 x+0.775$ & 0.7034 & \\
\hline
\end{tabular}

\footnotetext{
**Determined in the culture medium MNM.
} 
the needed for pre-selection in contaminated substrate for using in polluted areas.

The different media influenced the copper-resistance for the different isolates. This variation in response of ectomycorrhizal fungi to metals was reported by Galli et al. (2003), which attributed to the complexion of heavy metals in the matrix of the solid media, altering its availability. Blaudez et al. (2000) verified that the use of solid or liquid medium did not affect the growth. However, other authors indicated a lower tolerance of ectomycorrhizal fungi in the liquid medium, causing tolerance variation of ectomycorrhizal genera when added to the same metal doses in the solid medium (Colpaert and Van Assche, 1988).

The higher production of mycelia mass for the ectomycorrhizal isolates in higher copper doses may have occurred due to mechanisms of excretion of organic molecules, mainly of di- and tri-carboxylic acids which form chelates with the metal ions $(5,28)$ and/or increase in the formation of fungal melanin which act in the tolerance mechanisms of the ectomycorrhizal fungi to the heavy metals (Grazziotti et al., 2001). Ahonen-Jonnarth et al. (2008) observed that in ectomycorrhizal isolates exposed to different concentrations of heavy metals, which there is a stimulus for production of organic acids such as oxalic, citric, lactic, acetic, propionic, butyric and iso-butyric, which act in the chelation mechanisms of heavy metals.

The $\mathrm{CL}_{50}$ values in liquid were lower than the other found in solid medium, which confirms the reports of other authors (8). The results of $\mathrm{CL}_{50}$ found with studied isolates were different from that observed by other authors when studying tolerance of ectomycorrhizal fungi to heavy metals in liquid medium. Grazziotti et al. (2001) found $\mathrm{CL}_{50}$ values for the fungi Pisolithus tinctorius and Suilus bovinus to the copper of $1.18 \mathrm{mmol} \mathrm{L}^{-1}$ and $0.12 \mathrm{mmol} \mathrm{L}^{-1}$, respectively. Tam (1995) found $\mathrm{CL}_{50}$ values in liquid medium for the fungus Pisolithus tinctorius between 1.5 and $3.0 \mathrm{mmol}$ $\mathrm{L}^{-1}$, considering its tolerances to $\mathrm{Zn}$ and $\mathrm{Cu}$, respectively. Colpaert and Van Asche (1998) showed values of $\mathrm{CL}_{50}$ for Paxillus involutus in liquid medium between 392 and $785 \mu \mathrm{mol}$; however for Amanita muscaria the $\mathrm{CL}_{50}$ was between 785 and $2360 \mu \mathrm{mol}$, showing a high variation in the response of the ectomycorrhizal fungi for copper doses. Blaudez et al. (2000) observed that the fungus Suillus luteus showed higher values of $\mathrm{CL}_{50}$ than Pisolithus involutus in the different concentrations of $\mathrm{Cd}, \mathrm{Cu}, \mathrm{Ni}$ and Zn.

Different response of ectomycorrhizal fungi for the tolerance to heavy metals has been observed by different authors (Colpaert and Van Assche, 1992; Howe et al., 1997; Colpaert et al., 2000; Grazziotti et al., 2001). Howe et al. (1997) observed higher tolerance to the copper in the fungus Paxillus involutus compared to isolates of Laccaria laccata and Scleroderma citrinum, and higher tolerance to the cadmium in Suillus granulatus compared to Suillus variegatus. Grazzioti et al. (2001) also found differences in copper-tolerance in two ectomycorrhizal isolates, Suillus bovinus and Pisolithus tinctorius, which the Suillus bovinus was less tolerant.

The pigment production by ectomycorrhizal fungi can be a favourable characteristic to copper-resistance. According to Forgaty and Tobin (Forgaty and Tobin, 1996), albino isolates showed reduced capacity or cannot produce melanin in the presence of copper excess in the culture medium. The specific production of extracellular elements followed the same trend in total pigment production in the isolates of solid medium. These differences in the extracellular pigment production among isolates show intrinsic physiological differences when subjected to stress of copper element in controlled environments.

The pigments which generated brown colour in the medium were not identified but showed typical characteristics of extracellular melanin which are induced by heavy metals (Colpaert, 2008; Gadd and De Rome, 1988). The production of extracellular melanin and their effect on tolerance of ectomycorrhizal fungi in relation to heavy metals was reported by other authors (Colpaert and Van Assche, 1988; Grazziotti et al., 2001, Martino et al., 2003). This protein is related to copper adsorption showing one of the main mechanisms of tolerance to metals through compartmentalization exercised by carboxylic, phenolic, hydroxyl and amine groups, which have potential sites for connection or bioadsorption of metallic ions (Forgaty and Tobin, 1996; Fomina et al., 2005). The straight relation between melanin and copper is due to the capacity of metals connection with fungal melanin to occur in the following order: $\mathrm{Cu}>\mathrm{Cd}>\mathrm{Mn}>\mathrm{Zn}$ (Saiz-Jiminez and Shafizadeh, 1984).

In summary, the ectomycorrhizal isolate UFSCPt116 showed higher copper-resistance in all studied concentrations, while the fungus UFSC-Pt24 shows high resistance from $0.50 \mathrm{mmol} \mathrm{L}^{-1}\left(32 \mathrm{mg} \mathrm{L}^{-1}\right)$ of copper in solid culture medium. The fungi UFSC-Pt24 and UFSC-Sc124 showed higher copper-resistance in liquid culture medium. In high copper doses, the higher production of dry biomass was obtained with the isolate UFSC-Pt24. The highest production of extracellular pigment is obtained with the fungus UFSC-Pt116 and the highest specific production of extracellular pigment was with the fungus UFSC-Sc124. However the isolates of ectomycorrhizal fungi UFSC-Pt24 and UFSC-Pt116 can be important candidates to survive in copper contaminated areas and with these resistance characteristics, they have shown important agents in the symbiosis with plants in these contaminated sites.

\section{References}

Ahonen-Jonnarth U, Van Hees PAW, Lundströuml US, Finlay RD (2008) Organic acids produced by mycorrhizal Pinus sylvestris exposed to elevated aluminium and heavy metal concentration. New Phytol 146:555-567.

Andreazza R, Pieniz S, Wolf L, Lee MK, Camargo FAO, Okeke $\mathrm{BC}$ (2010) Characterization of copper biosorption and bio- 
reduction by a highly copper resistant bacterium isolated from copper-contaminated vineyard soil. Sci Total Environ 408:1501-1507.

Andreazza R, Okeke BC, Pieniz P, Brandelli A, Lambais MR, Camargo FAO (2011) Bioreduction of $\mathrm{Cu}(\mathrm{II})$ by cell-free copper reductase from a copper resistant Pseudomonas sp. NA. Biol Trace Elem Res 143:1182-1192.

Bell R, Evans CS, Roberts ER (1988) Decreased incidence of mycorrhizal root tips associated with soil heavy metal enrichment. Plant Soil 106:143-145.

Bellion M, Courbot M, Jacob C, Blaudez D, Chalot M (2006) Extracellular and cellular mechanisms sustaining metal tolerance in ectomycorrhizal fungi. FEMS Microbiol 254:173-181.

Blaudez D, Jacob C, Turnau K, Colpaert V, Ahonen-Jonnarth U, Finlay R, Botton B, Chalot M (2000) Differential responses of ectomycorrhizal fungi to heavy metals in vitro. Mycol Res 104:1366-1371.

Brundrett M, Bougher N, Dell B, Grove T, Malajczuk N (1996) Working with Mycorrhizas in Forestry and Agriculture. Aciar, Canberra.

Colpaert JV, Van Assche JA (1988) Heavy metal tolerance in some ectomycorrhizal fungi. Funct Ecol 1:415-421.

Colpaert JV, Van Assche JA (1992) Zinc toxicity in ectomycorrhizal Pinus sylvestris. Plant Soil 143:201-211.

Colpaert JV, Vandenkoornhuyse P, Adriaensen K, Vangronsveld $\mathrm{J}$ (2000) Genetic variation and heavy metal tolerance in the ectomycorrhizal basidiomycete Suillus luteus. New Phytol 147:367-379.

Colpaert JV (2008) Heavy metal pollution and genetic adaptations in ectomycorrhizal fungi: Stress in yeast and filamentous fungi. Br Mycol Sy 27:157-173

Ferreira DF (2008) Sisvar: um programa para análises e ensino de estatística. Rev Symp 6:36-41.

Fomina MA, Alexander IJ, Colpaert JV, Gadd G (2005) Solubilization of toxic metal minerals and metal tolerance of mycorrhizal fungi. Soil Biol Biochem 37:851-866.

Forgaty RV, Tobin JM (1996) Fungal melanins and their interactions with metal. Enz Microb Technol 19:311-317.

Gadd GM, De Rome L (1988) Biosorption of copper by fungal melanin. App Microbiol Biotechnol 29:610-617.

Gadd GM (1993) Interactions of fungi with toxic metals. New Phytol 124:25-60.

Gadd GM (2004) Microbial influence on metal mobility and application for bioremediation. Geoderma 122:109-119.

Gadd GM (2007) Geomycology: Biogeochemical transformations of rocks, minerals, metals and radionuclides by fungi, bioweathering and bioremediation. Mycol Res 111:3-49.

Galli U, Meier M, Brunold C (1993) Effect of cadmium on non-mycorrhizal and mycorrhizal Norway spruce seedlings (Picea abies (L.) Karst.) and its ectomycorrhizal fungus Laccaria laccata (Scop. Ex fr.) Bk \& Br.: Sulphate reduction, thiols and distribution of the heavy metal. New Phytol 125:873-843.

Grazziotti PH, Siqueira JO, Moreira FM, Carvalho D (2001) Efeito de $\mathrm{Zn}, \mathrm{Cd}$ e $\mathrm{Cu}$ no comportamento de fungos ectomicorrízicos em meio de cultura. Rev Brás Ciên Solo 25:831837.

Hartley J, Cairney JWG, Sanders FE, Meharg AA (1997) Toxic interactions of metal ions $\left(\mathrm{Cd}^{2+}, \mathrm{Pb}^{+2}, \mathrm{Zn}^{+2}\right.$ and $\left.\mathrm{Sb}^{-3}\right)$ in vitro biomass production of ectomycorrhizal fungi. New Phytol 137:551-562.

Howe R, Evans RL, Ketteridge SW (1997) Copper - Binding proteins in ectomycorrhizal fungi. New Phytol 135:123-131.

Johansson EM, Fransson PMA, Finlay RD, Van Hees PAW (2008) Quantitative analysis of exudates from soil-living basidiomycetes in pure culture as a response to lead, cadmium and arsenic stress. Soil Biol Biochem 40:2225-2236.

Khan AG (2001) Relationships between chromium biomagnification ratio, accumulation factor, and mycorrhiza in plants growing on tannery effluent-polluted-soil. Environ Inter 26:417-423.

Martino E, Turnau K, Girlanda M, Bonfante P, Perotto S (2000) Ericoid mycorrhizal fungi from heavy metal polluted soils: Their identification and growth in the presence of zinc íons. Mycol Res 104:338-344.

Martino E, Perotto S, Parsons R, Gadd GM (2003) Solubilization of insoluble inorganic zinc compounds by ericoid mycorrhizal fungi derived from heavy metal polluted sites. Soil Biol Biochem 35:133-141.

Marx DH (1969) The influence of ectotrophic mycorrhizal fungi on the resistance of pine roots to pathogenic infections. I. Antagonism of mycorrhizal fungi to root pathogenic fungi and soil bacteria. Phytopathology 59:153-163.

Nehls U, Göhringer F, Wittulsky S, Dietz S (2010) Fungal carbohydrate support in the ectomycorrhizal symbiosis: A review. Plant Biol 12:292-301.

Perotto R, Martino E (2001) Molecular and cellular mechanisms of heavy metal tolerance in mycorrhizal fungi: What perspectives for bioremediation? Minerva Biotechnol 13:5563.

Rühling A, Söderstrom B (1990) Changes in fruibody production of mycorrhizal and litter decomposing macromycetes in heavy metal polluted coniferous forests in North Sweden. Water Air Poll 49:375-387.

Saiz-Jiminez C, Shafizadeh F (1984) Iron and copper binding by fungal phenolic polymers: An electron spin resonance study. Cur Microbiol 10:281-286.

Sharples JM, Meharg AA, Chambers SM, Cairney JW (2001) Arsenate resistance in the ericoid mycorrhizal fungus Hymenoscyphus ericae. New Phytol 151:265-270.

STATSOFT Inc (1996) Statistic for Windows. Computer program manual. Tulsa.

Tam PCF (1995) Heavy metal tolerance by ectomycorrhizal fungi and metal amelioration by Pisolithus tinctorius Mycorrhiza 5:181-187.

Wang J, Huang Y, Jiang XY (2011) Influence of ectomycorrhizal fungi on absorption and balance of essential elements of Pinus tabulaeformis seedlings in saline soil. Pedosphere 21:400-406.

Van Tichelen KK, Colpaert JV, Vangronsveld J (2001) Ectomycorrhizal protection of Pinus sylvestris against copper toxicity. New Phytol 150:203-213.

Zheng W, Fei Y, Huang Y (2009) Soluble protein and acid phosphatase exuded by ectomycorrhizal fungi and seedlings in response to excessive $\mathrm{Cu}$ and Cd. J Environ Sci 21:16671672.

All the content of the journal, except where otherwise noted, is licensed under a Creative Commons License CC BY-NC. 